\title{
Keeping An Eye On Environmental Quality in Tanzania as Trade, Industrialization, Income and Urbanization Continue To Grow
}

\author{
Mwoya Byaro ( $\square$ mwoyabyaro2018@gmail.com ) \\ Institute of Rural Development Planning \\ Gemma Mafwolo \\ Institute of Rural Development Planning \\ Hozen Mayaya \\ Institute of Rural Development Planning
}

\section{Research Article}

Keywords: Carbon dioxide emission, environmental quality, ARDL

Posted Date: November 23rd, 2021

DOI: https://doi.org/10.21203/rs.3.rs-985923/v1

License: (1) This work is licensed under a Creative Commons Attribution 4.0 International License.

Read Full License

Version of Record: A version of this preprint was published at Environmental Science and Pollution Research on April 5th, 2022. See the published version at https://doi.org/10.1007/s11356-022-19705-x. 


\section{Abstract}

By applying the ARDL (autoregressive distributed lag) bounds testing method, this study examines the short and long-term dynamic relationship between carbon dioxide (CO2) emissions, economic growth (Gross Domestic Product), industrialization, trade and urban population in Tanzania from 1990 to 2020. The study found that economic growth, trade, industrialization, and the urban population all contributed to the increase in environmental degradation (i.e. carbon dioxide emissions). However, we found that financial credit (i.e. domestic credit to the private sector) reduces carbon dioxide emissions, but its effects are not significant. Our findings revealed that economic growth (i.e. income) was responsible for both short and long-term increases in carbon dioxide emissions in Tanzania. Economic growth is harmful to the environmental quality above a threshold value of $6.23 \%$. Our findings suggest that policy makers should monitor and use the threshold levels to manage carbon dioxide emissions and to protect the environmental quality. Further, a strong focus should be placed on formulating environmental policies (i.e. carbon tax policy) as industrialization, urban population, economic growth and trade continue to grow in future, restricting carbon dioxide emissions and safeguarding the environment.

\section{Introduction}

Tanzania is one of the sustainable communities where people want to live now and work in the future (See for example, WHO, 2012). Generally, people prefer to work in areas that are highly associated with a healthy environment. However, environmental quality remains a major obstacle to achieving sustainable development goals, both in developed and developing countries (Efobi et al., 2019). As a result, it has a significant impact on people's quality of life (Coan and Holman 2008; Kahn, 2002). This stresses the United Nations (2015) to announce the sustainable development Goals (SDGs) that requires all countries to take immediate action to prevent climate change and its consequences. It's also important to note that environmental quality is still a mystery, especially for countries that compete in nation's economic growth. In regard to this competition, political leaders are forced to make decisions that are subject to change in the future. As a result, policymakers in many developing countries are under pressure to increase these variables to the calculated thresholds (i.e. turning point) to achieve the desired impact on environmental improvement (Omri et al., 2019).

Despite some progress in environmental sustainability around the world, the quality of environmental reporting has not been universally accepted due to its difficulty in providing accurate and transparent information (Amran et al., 2014). Furthermore, non-financial disclosure has long been criticized for its lack of relevance and credibility (Baalouch et al., 2019; Kolk, 2008). No universal agreement exists on environmental quality and sustainability (Shaker, 2015), but developing countries have been asked about these ground rules. As of February 2005, the Kyoto Protocol was the first agreement that attempts to control greenhouse gas emissions and provides a schedule for achieving those reductions (Akbostanci et al. 2011). 
In general, environmental quality issues have gained attention in recent years because of the need to protect biodiversity, human health, and economic activities (Yameogo et al., 2020). Further, carbon emissions tend to rise faster in developing countries than in advanced economies (Bahera and Dash, 2017). Similarly, the five key Sustainable Development Goals (SDGs) of 2030 address the environmental determinants of health and include issues of water, sanitation, and hygiene, air quality, chemical safety, and climate action (PAHO, 2021). All countries in the world are striving to reduce greenhouse gas emissions (i.e. CO2) and create a small proportion of carbon in the economy. Although the majority of African countries contribute less to green house gas emissions, they are extremely vulnerable to climate change (See, Edmonds eta I., 2020; Guillaumont and Simonet, 2011). With this in mind, and for Tanzania to achieve sustainable development growth, it requires low or no environmental pollution that depends on its level of economic activities and institutional setting (See Byaro and Kinyondo, 2020). For Tanzania's economy to be more sustainable in terms of development; trade, financial development, industrialization, and urbanization can all contribute to its growth. Tanzania is classified as a low-middle-income country and its economic performance has been impressive in recent years. Thus, keeping an eye on the quality of the environment cannot be ignored as the country continues to grow in terms of income, trade, financial industry, urban population, and industrialization. To this end, our study contributes to the existing literature in developing countries in a number of ways. First and foremost, this is the first study to examine the effects of trade, economic growth (i.e. income), and urban population on environmental quality in Tanzania over the year 1990 to 2020 . Second, it adds the role of industrialization (i.e. manufacturing value added) and financial development in explaining carbon dioxide emissions as a measure of environmental quality in Tanzania. There is evidence that the link between economic growth, carbon dioxide emissions, urbanization, financial development, industrialization and trade in developing countries has not been thoroughly studied (See, Odugbesan and Rjoub, 2020; Martinez and Maruotti, 2011). Few studies from developing countries are based on country-specific analysis. For instance, a country-specific study in Tanzania examined the dynamic relationship between energy consumption, environmental pollution and economic growth using a time series of data from 1975 to 2013 (Albiman et al., 2015). Third, some literature has shown that countries in sub-Saharan Africa (i.e. including Tanzania) would be the hardest hit by the effects of climate change (See, Asongu and Odhiambo, 2020a; Asongu and Odhiambo, 2020b). Last but not least, our study uses the autoregressive distributed lag model (ARDL) to control the endogeneity of variables among economic growth, financial development, industrialization, trade openness, and urban population. In addition, we combined a set of threshold values to give decision-makers a clear picture of how to manage environmental quality in order to reduce carbon dioxide emissions. Figure 1 below shows the normalized data between carbon dioxide emissions and economic growth from the year 1990 to 2020 in Tanzania. An increase in carbon dioxide emissions (metric tons per capita) corresponds to an increase in economic growth (i.e., GDP). As the economy grows, there is a chance that carbon dioxide emissions will raise. This can affect the atmosphere and cause global warming, which in turn causes climate change.

Overall, Tanzania has negligible carbon dioxide per capita emissions, estimated at 0.2 tons per carbon dioxide emissions (World Development Indicators, 2021). This is very small compared to China where 
carbon dioxide emissions per capita in 2019 were 8.12 tons per capita. However, it is still important for Tanzania in this early stage of development to examine whether carbon dioxide emissions can actually affect environmental quality or not. Some literature has also noted that agriculture, energy, waste and industrial processes and product use all contribute to Tanzania's greenhouse gas emissions (NBS, 2019). Despite decades of high carbon dioxide emissions, for example, from 0.08 tons per carbon dioxide emissions in 1990 to 0.27 tons per carbon dioxide emissions in 2019 (World Development Indicators, 2021), Tanzania has made few efforts to control and implement necessary environmental policies. Over time, thermal power facilities have been built to increase carbon dioxide emissions (NBS, 2019). Furthermore, old vehicles in traffic continue to emit high levels of environmental pollution in the country.

Our preliminary findings indicate that industrialization, trade, economic growth, and urban population all deteriorate environmental quality and have a significant and positive impact on carbon dioxide emissions in Tanzania from 1990 to 2020.

The remainder of this study is organized as follows. Section 2 reviews the literature. The methodology and data are described in section 3. Empirical results and discussion are described in section 4 while section 5 concludes.

\section{Theoretical And Empirical Literature Review}

Three streams of research have been identified in the literature about this topic. The first one is based on the environmental economics and relies heavily on a joint analysis of GDP and pollution. A large part of previous research has been devoted to testing the Environmental Kuznets Curve (EKC) hypothesis, which states that pollution and GDP are related in an inverted U-shape (See, Muhammad et al., 2020; Grossman and Krueger, 1991). The hypothesis further stipulates that in the early stages of economic growth, environmental degradation increases with per capita income, but after reaching a certain threshold level, it declines. The second line of inquiry is derived from studies in international economics and focuses on international trade, environmental pollution and GDP growth. Although the empirical relationship between international trade, GDP and environmental pollution is not clear, studies suggest that international trade can have an impact on the environmental quality due to an increase of income or production (See for example; Frankel and Romer, 1999; Frankel and Rose, 2005). The third strand of literature examines the relationship between energy consumption and output related to economic growth, as higher economic development necessitates higher energy consumption (Halicioglu, 2009). However, environmental quality is not universally agreed in understanding and practice since many nations have been striving to accommodate their environment in regards to political, social, and economic needs.

Due to the lack of a uniform theoretical framework, previous research has tended to focus on the sociopolitical and economic factors that influence non-financial reporting (Braam et al., 2016). Similarly, environmental quality determinants are complex, subjective and multidimensional that cannot be expressed in any theoretical perspective because it depends on complementary forces (Baalouch et al., 2019). Preserving environmental and natural resources is one of the most important factors in ensuring 
the sustainability of well-being over time. However, measuring environmental indicators are difficult: first, the size of the impact of current environmental factors on future well-being is uncertain; and second, there are few comparable indicators that meet agreed standards (WHO, 2012). Furthermore, prior research has failed to provide an accurate measure of environmental disclosure quality due to a lack of convincing theoretical underpinning and the subjectivity surrounding the developed proxies (Baalouch et al., 2019).

Our study employs some empirical models based on Yameogo et al. (2020) together with other empirical studies (Li and Wei; 2021; Opuku and Aluko, 2021; Opuku and Boachie, 2020; Boutabba, 2014; Akbostanci et al., 2011; Tamazian et al., 2009). For example, Akbostanci et al. (2011) observed that variations in carbon dioxide emissions in the Turkish manufacturing industry were mostly due to changes in total industrial activity and energy intensity. Other previous empirical findings have shown that per capita income, financial development, foreign direct investment (FDI), and foreign trade positively contributes to environmental degradation (Zafar et al., 2020; Omri et al., 2019; Salahuddin et al., 2018). Similarly, Ahad and Khan (2016) used the ARDL techniques to analyse the relationship among globalization, economic growth, energy use and environmental quality in Bangladesh showed that economic growth tends to improve environmental quality. In turn, Ibrahim and Law (2016) found trade openness to increase environmental pollution due to poor institutional framework. However, Li et al. (2015) examined this relationship in 134 countries and found a negative impact of trade on environmental pollution. Finally, the detailed literature is well explained in the discussion section.

\section{Data And Methodology}

\subsection{ARDL Model Estimation}

We used the ARDL (Autoregressive Distributed Lag) approach to determine the environmental quality in Tanzania. It determines whether the data in their levels are stationary at level I(0) or stationary at first differences I(I) (Pesaran et al., 2001). This model has several advantages. First, it operates when the sample size is very small and sometimes it does not require pre-testing of the orders of integration (Pesaran and Shin, 1999; Pesaran et al., 2001). Second, it addresses the model autocorrelation and endogeneity (Murshed, 2021, Sarkodie and Ozturk, 2020; Byaro and Lemnge, 2018). Third, it predicts both short and long-term elasticity and uses different lag lengths for different variables. Fourth, the model identifies asymptotic critical value bounds, showing that variables are integrated at first differences I(1) or at level I (0) (Perasan, 2001). The upper bound represents a critical values of I(1), while the lower bound represents a critical values of $\mathrm{I}(0)$. If the F-test statistics are higher than their respective critical values, a long-term association between the variables is established (Perasan, 2001). If the test statistic falls below the upper critical value, the null hypothesis of no cointegration cannot be rejected. If the Fstatistic obtained falls between the lower and upper bound values, the results are ambiguous.

We used the ARDL model as follows:- 


$$
\begin{aligned}
& \begin{aligned}
\Delta \mathbf{L}(\mathrm{CO2})_{t}=\alpha_{0}+\sum_{i=1}^{q} & \alpha_{1 i} \Delta \mathbf{L}(\mathrm{CO} 2)_{\mathrm{t}-\mathrm{i}}+\sum_{i=1}^{q} \alpha_{2 i} \Delta \mathbf{L}(\mathrm{URBAN})_{t-i} \\
& +\sum_{i=1}^{q} \alpha_{3 i} \Delta \mathbf{L}(\mathrm{IND})_{t-i}+\sum_{i=1}^{q} \alpha_{4 i} \Delta \mathbf{L}(\mathrm{GDP})_{t-i}+\sum_{i=1}^{q} \alpha_{5 i} \Delta L(\mathrm{TRADE})_{t-i}+\sum_{i=1}^{q} \alpha_{6 i} \Delta L(\mathrm{CREDIT})_{t-i}+
\end{aligned} \\
& \lambda_{1} \mathbf{L}(\mathrm{CO2})_{t-1}+\lambda_{2} \mathbf{L}(\mathrm{URBAN})_{t-1}+\lambda_{3} \mathbf{L}(\mathrm{IND})_{t-1}+\lambda_{4} \mathbf{L}(\mathrm{GDP})_{t-1}+\lambda_{5} \mathbf{L}(\mathrm{TRADE})_{t-1}+\lambda_{6} \mathbf{L}(\mathrm{CREDIT})_{t-1}+\mu_{t}
\end{aligned}
$$

Where CO2 represent carbon dioxide emission, IND (Industrialization as manufacturing value added), URBAN (population living in urban areas), GDP (Economic growth), CREDIT (domestic credit to private sector), TRADE (trade openness), $\Delta$ represent the first difference operator and $L$ shows a natural logarithm while $\mathrm{q}$ is the optimal lag length. Long-term relationships are represented by the first through sixth expressions $\left(\lambda_{1}-\lambda_{6}\right)$ on the right. The first until fifth expressions on the right side correspond to the long-run relationship. The summation sign $\left(a_{1}-a_{6}\right)$ shows a short run dynamics and $\mu_{t}$ represent the error term or white noise. The null hypothesis was no cointegration among the variables.

If there is cointegration, it is possible to estimate the long run and short term models. Then the short run ARDL model is described as follows:-

$$
\begin{aligned}
\Delta \mathbf{L}(\mathbf{C O 2})_{t}=\alpha_{0}+\sum_{i=1}^{q} \alpha_{1 i} \Delta \mathbf{L}(\mathbf{C O} 2)_{\mathrm{t}-\mathrm{i}}+\sum_{i=1}^{q} \alpha_{2 i} \Delta \mathbf{L}(\mathrm{URBAN})_{t-i}+\sum_{i=1}^{q} \alpha_{3 i} \Delta \mathbf{L}(\mathrm{IND})_{\mathrm{t}-\mathrm{i}}+\sum_{i=1}^{q} \alpha_{4 i} \Delta \mathbf{L}(\mathbf{G D P})_{t-i} \\
+\sum_{i=1}^{q} \alpha_{5 i} \Delta \mathbf{L}(\mathrm{TRADE})_{t-i}+\sum_{i=1}^{q} \alpha_{6 i} \Delta \mathbf{L}(\mathrm{CREDIT})_{t-i}+\mathrm{\gamma} E C M_{t-1}+\mu_{t}
\end{aligned}
$$

While $\mathbb{B}$ is the coefficient of the Error Correction Model (ECM). The ECM shows a speed at which the dependent variable adjusts to equilibrium and it must be negative and statistically significant.

\subsection{Data sources}

Annual secondary data from the year 1990 to 2020 on all variables was sourced from the World Bank Development Indicators Database (2021). Carbon dioxide emissions as a proxy for environmental quality are measured in metric tons per capita. Economic growth is expressed in GDP per capita at a constant 2010 US dollars. Urban population growth is measured in annual percentages. Industrialization is expressed as manufacturing value added in constant 2010 US dollars; domestic credit to the private sector is measured as a percentage share of GDP; trade is measured as a percentage of GDP (Gross Domestic Product).

\section{Results And Discussion}

Table 1 shows a summary of descriptive statistics of the variables. A Jarque-Bera test statistics with probability value of zero, show that all variables confirm normality (i.e. normal distribution). 
Table 1

Descriptive Statistics

\begin{tabular}{|lllllll|}
\hline & CO2 & CREDIT & GDP & TRADE & URBAN & INDUSTRY \\
\hline Mean & 0.14 & 9.61 & 670.39 & 42.17 & 4.95 & 8.54 \\
\hline Median & 0.14 & 11.26 & 637.01 & 42.77 & 5.14 & 8.66 \\
\hline Maximum & 0.23 & 14.61 & 985.45 & 65.69 & 5.39 & 10.98 \\
\hline Minimum & 0.07 & 2.94 & 476.53 & 23.98 & 3.97 & 6.27 \\
\hline Std. Dev. & 0.06 & 3.94 & 173.34 & 12.17 & 0.48 & 1.10 \\
\hline Jarque-Bera & 3.08 & 3.44 & 2.98 & 1.37 & 5.59 & 0.33 \\
\hline Probability & 0.21 & 0.17 & 0.23 & 0.50 & 0.06 & 0.84 \\
\hline Observations & 31 & 31 & 31 & 31 & 31 & 31 \\
\hline $\begin{array}{l}\text { Note: GDP= Gross Domestic Product, URBAN= Urban population growth, C02= Carbon dioxide } \\
\text { emission. }\end{array}$ & & & & & & \\
\hline
\end{tabular}

Table 2 shows the unit roots test whether the data is stationary or non-stationary at levels or stationary at first differences. We found almost all variables to be stationary at first difference except for the urban population which is stationary at level.

Table 2

Unit roots test

\begin{tabular}{|lll|}
\hline \multicolumn{3}{|c|}{ ADF } \\
\hline Variables & At level & 1st Difference Order of Integration \\
\hline LURBAN & $-5.73^{\star \star \star}$ & $-1(0)$ \\
\hline LCREDIT & -2.39 & $-6.24 * * * 1(1)$ \\
\hline LCO2 & -2.12 & $-5.04 * * * 1(1)$ \\
\hline LTRADE & -2.44 & $-14.04^{\star * *} 1(1)$ \\
\hline LINDUSTRY & -2.53 & $-6.06 * * * 1(1)$ \\
\hline LGDP & -2.36 & $-4.59 * * * 1(1)$ \\
\hline Source: Authors computation $(2021)$ \\
\hline
\end{tabular}

ADF $=$ Augmented Dick Fuller Test, ${ }^{* \star *}=$ P-value statistically at $1 \%$ critical values and $P<0.001$, 
$\mathrm{L}=$ Natural logarithm

After investigating the unit root tests, we conducted the ARDL bound testing. Table 3 shows the results of the bound test (long run relationship of variables). We conclude that there is a long-run relationship between carbon dioxide emissions, economic growth, trade, industrialization, domestic credit to the private sector, and urban population because the calculated F-statistics is greater than the upper bounds (i.e., 4.68).

Table 3

ARDL Bounds Test

\begin{tabular}{|lll|}
\hline \multicolumn{2}{|l|}{ Null Hypothesis: No long run relationship } \\
\hline Test statistic & Value & $\mathbf{k}$ \\
\hline F- Statistic & $\mathbf{9 . 3 1}$ & $\mathbf{5}$ \\
\hline Critical value bounds & Lower Bound, I(0) & Upper Bound I(1) \\
Significance & \\
\hline $10 \%$ & 2.26 & 3.35 \\
\hline $5 \%$ & 2.62 & 3.79 \\
\hline $2.5 \%$ & 2.96 & 4.18 \\
\hline $1 \%$ & 3.41 & 4.68 \\
\hline Source (Authors computation, 2021) \\
\hline
\end{tabular}

After testing the bounds test, we selected the maximum lag in the ARDL approach as $(2,0,1,3,3,0)$ chosen automatically by the AIC (Akaike Information Criteria) in the top 20 models shown in Figure 2 . The lower the values of AIC, the better the model.

Table 4 summarizes the short and long-run relationships among the variables. The findings show that most carbon dioxide emissions increases were attributed to economic growth followed by industrialization, urban population growth and trade. 
Table 4

Regression results for carbon dioxide emission

\begin{tabular}{|c|c|c|c|c|}
\hline \multicolumn{5}{|l|}{ A: Short Run Model } \\
\hline Variable & coefficient & std. error & t-statistic & probability \\
\hline $\mathrm{D}(\mathrm{CREDIT})$ & -0.17 & 0.13 & -1.23 & 0.23 \\
\hline $\mathrm{D}(\mathrm{GDP})$ & 6.05 & 1.41 & 4.28 & $0.001 * \star \star$ \\
\hline D(INDUSTRIALIZATION) & 1.02 & 0.38 & 2.68 & $0.02^{\star \star}$ \\
\hline D(URBANIZATION) & 0.12 & 0.03 & 3.35 & $0.01 * \star$ \\
\hline D(TRADE) & 0.28 & 0.12 & 2.29 & $0.04^{\star \star}$ \\
\hline $\mathrm{ECM}_{\mathrm{t}-1}$ & -0.54 & 0.27 & -1.97 & $0.03^{* *}$ \\
\hline \multicolumn{5}{|l|}{ B: Long run Model } \\
\hline CREDIT & -0.32 & 0.33 & -0.97 & 0.35 \\
\hline GDP & 1.78 & 0.44 & 4.03 & $0.001^{\star \star \star}$ \\
\hline INDUSTRIALIZATION & -1.11 & 0.96 & -1.16 & 0.27 \\
\hline URBANIZATION & -0.26 & 0.31 & -0.85 & 0.41 \\
\hline TRADE & 0.51 & 0.33 & 1.58 & 0.14 \\
\hline Constant & -12.12 & 3.79 & -3.19 & $0.01 * \star$ \\
\hline \multicolumn{5}{|l|}{ C: Diagnostic Tests } \\
\hline \multicolumn{4}{|c|}{ Breusch-Godfrey Serial Correlation LM Test } & 0.36 \\
\hline \multicolumn{4}{|l|}{ Heteroskedasticty } & 0.93 \\
\hline \multicolumn{5}{|l|}{ Observations ( $\mathrm{N}=31$ years) } \\
\hline \multicolumn{5}{|c|}{$\begin{array}{l}\text { Note: } * * * \text { indicate significance at } 1 \% \text { level, and } * * \text { indicate significance at } 5 \% \text { levels. } E C M=e r r o r \\
\text { correction term, } D=\text { presents short run, and all variables are in natural logarithm. }\end{array}$} \\
\hline
\end{tabular}

The short-run findings show that economic growth (i.e. GDP per capita), industrialization (i.e. manufacturing value added in industry), urban population, and trade activities lead to an increase of carbon dioxide emission in the country. However, in the long-run, only economic growth (i.e., income) leads to an increase in carbon dioxide emissions. Since the p-value was greater than 0.10 , the diagnostic tests showed that the results were robust and no serial correlation and heteroskedasticity were present. A unit increase of GDP per capita (income) by $1 \%$ is associated with a $6.05 \%$ increase in carbon dioxide emission in the short run. Similarly, in the short-run, increases in industrialization (i.e. manufacturing 
value added in industry) trade, and urban population have positive and statistically significant effects on the increase in carbon dioxide emissions in Tanzania.

Even though Tanzania's $\mathrm{CO} 2$ emissions are supposed to be small, such large coefficients of estimate in industrialization and GDP on carbon dioxide emissions are alarming. For instance, in the short run, an increase of $1 \%$ in urban population, trade, and industrialization increases carbon dioxide emissions by $0.12 \%, 0.28 \%$, and $1.02 \%$ respectively. Similarly, except for economic growth (i.e. income), trade, domestic credit to the private sector, industrialization and urban population, were found to have no long-run effect on carbon emissions. The error correction term is also negative and statistically significant as expected.

To check whether the results are robust, we ran additional analysis (See, Table 5) using a non-linear threshold value estimate on the impact of trade, industrialization, economic growth, and urbanization on environmental quality (i.e., proxy for carbon dioxide emission). The importance of these threshold values is to provide a clear insight to decision makers on the management of environmental quality to control carbon dioxide emissions.

Table 5

Threshold value estimates of carbon dioxide emissions control

\begin{tabular}{|c|c|c|c|c|}
\hline Threshold value & Variable & Coefficient & Std error & Probability \\
\hline \multirow[t]{3}{*}{$6.23 \%$} & GDP & & & \\
\hline & $\mathrm{GDP}>6.23$ & 1.43 & 0.22 & $0.000 * \star \star$ \\
\hline & Constant & -11.34 & 1.49 & \\
\hline \multirow[t]{3}{*}{$2.03 \%$} & Industrialization & & & \\
\hline & Industry $>2.03$ & -2.93 & 1.28 & $0.03^{* *}$ \\
\hline & Constant & 4.55 & 2.74 & 0.10 \\
\hline \multirow[t]{3}{*}{$1.63 \%$} & Urbanization & & & \\
\hline & Urbanization > 1.63 & -0.07 & 0.04 & $0.09 *$ \\
\hline & Constant & -1.68 & 0.11 & 0.000 \\
\hline \multirow[t]{3}{*}{$3.95 \%$} & Trade & & & \\
\hline & Trade $>3.95$ & -1.53 & 1.09 & 0.17 \\
\hline & Constant & 3.92 & 4.6 & 0.41 \\
\hline \multirow[t]{2}{*}{$3.73 \%$} & Trade $<3.73$ & 2.13 & 0.35 & $0.000 * \star \star$ \\
\hline & Constant & -9.28 & 1.18 & 0.000 \\
\hline
\end{tabular}


Table 5 shows that carbon dioxide emissions rise when economic growth exceeds the calculated threshold value of ( $>6.23$ percent), polluting the environment. Carbon dioxide emissions rise slightly but not significantly when economic growth falls below the estimated threshold value of 6.23 percent.

When economic growth falls below the estimated threshold value of 6.23 percent, carbon dioxide emissions rise slightly but not significantly. This implies that economic growth above the threshold level of $(6.23 \%)$ is statistically significant for deteriorating environmental quality. In regard to industrialization, the industrial threshold level above (2.04\%) reduces carbon dioxide emissions. Industries can reduce carbon dioxide emissions by adopting energy efficiency, fuel switching, and use of renewable energy (i.e. solar and wind) and recycling of materials. The uses of renewable energy resources in industry provide a cleaner and more sustainable energy system. Zhou and Li (2020) pointed out that, industrial restructuring is important for lowering carbon dioxide emissions. This suggests that industrial restraint is a viable strategy for achieving green growth.

The threshold level of the urban population above (1.63\%) in Tanzania reduces carbon dioxide emissions. Excessive urbanization might claim the benefits of high-level urbanization in terms of reducing carbon dioxide emissions (Zhang and Chen, 2017; Xiangyang and Guiqiu, 2011). Urbanization will certainly accelerate the development of urban infrastructure, which in turn facilitates the use of energy and the generation of carbon dioxide emission (Du et al., 2012). Further, urban areas have large agglomeration in terms of development that can facilitate the use of clean energy and cut carbon dioxide emissions (Du et al., 2012; Zhang and Chen, 2017).

Trade openness at the threshold level value below (3.73\%) increases carbon dioxide emissions, though not statistically significant. In this case, trade openness is linked to carbon dioxide emissions. It is clear that trade assists both rich and poor countries to grow faster and boost their economies. However, trade openness at the threshold level above (3.95\%) reduces carbon dioxide emissions. More industrial production output leads to increased trade, and such industrial processes result in emissions. Shahbaz et al. (2017) proposed new turning points in the relationship between trade openness and CO2 emissions. Using country-level, high, middle and lower-income country panel-level data sets, they found that carbon emissions initially rise with trade openness, and environmental quality begins to improve after trade openness reaches a certain threshold level at a later stage of economic development. In the same vein, Grossman and Krueger (1996) pointed out that as trade expands as a result of improved technologies and good environmental policies, it reduces carbon dioxide emissions. The coefficients of economic growth, trade openness in Table 5, are positive, significant, and similar to the coefficients sign we obtained in Table 4, implying that the relationship between carbon dioxide emissions and trade and economic growth is significant and robust.

Overall, industrialization leads to high economic growth, and this can lead to increased greenhouse gas emissions and climate change (See, Opuku and Aluko, 2021; Pata, 2018). Prioritizing industry expansion is a logical choice in the early phases of industrialization, but it adds to a significant increase in carbon 
emissions (Dong et al., 2021). Rehman et al. (2021) showed that industrialization has a positive impact on carbon dioxide emissions in Pakistan. Further, Aslam et al. (2021) showed that industrialization is one of the predictors of Chinese carbon dioxide emissions. The most significant contributors to increased environmental pollution are industrial activities such as cement, iron, and steel production (Akbostanci et al., 2011). In industrialization, carbon dioxide is emitted in the production processes such as burning of fossil fuel combustion. However, industries can reduce co2 emission for adopting energy efficiency, fuel switching, and the use of renewable energy (i.e. solar and wind) and recycling of materials.

In many countries, economic policies and strategies are geared toward long-term economic growth. Economic growth, on the other hand, may have an impact on global warming and climate change (Salari et al., 2021). In turn, economists believe that policies that limit production potential may have a long-term negative and harmful impact on economic growth (Ricci, 2007). However, Grossman and Krueger (1995) argued that for countries to attain high economic growth, they needed more inputs in order to expand their outputs, resulting in an increase in waste and emissions caused by economic activity. Our findings show that economic growth (GDP) increased carbon dioxide emissions from 1990 to 2020 in Tanzania. This demonstrates the existence of the environmental Kuznets Curve (EKC). Tanzania is still in the early phases of economic development and its environmental degradation levels tend to rise significantly as income rises. This implies that the government and its people care more about economic development than environmental protection.

The term urbanization refers to a sociological phenomenon in which people migrate from rural to urban areas. Tanzania's urban population grew to 22.1 million people in 2020, accounting for 37 percent of the country's overall population (Statista, 2021). According to our findings, urbanization in Tanzania has resulted in a rise in carbon dioxide emissions. In addition, urbanization increases industrial and residential energy consumption, as well as the change from rural to industrial output among urban populations (Odugbesan and Rjoub, 2020). Likewise, increased energy consumption, which is recognized as a significant source of climate change, as well as greenhouse gas emissions like $\mathrm{CO} 2$, have originated from growth and urbanization (See, Zhang et al., 2021; Bakirtas and Akpolat, 2018; Wang et al., 2018; Behera and Dash, 2017; Heidari et al., 2015; Martinez and Maruotti, 2011). In a similar vein, large cities with higher per capita income are also associated with a high level of the urban population (Jedwab and Vollrath, 2015).

On the other hand, trade openness is one of the fundamental driving forces behind China's economic development (Sun et al., 2019). However, our study findings reveal that trade openness has positive and significant effects on the rise of carbon dioxide emission in Tanzania. This means that international trade is critical to the rapid rise in carbon dioxide emissions (Hakimi and Hamdi, 2016; Zhou et al., 2013). A good example is China, where the volume of carbon dioxide emissions embodied in interregional trade grew significantly from 2002 to 2010 (Xu et al., 2020). Grossman and Krueger (1993) noted that trade openness can have positive or negative effects on the economy. 
Some scholars claim that financial development improves environmental quality (i.e. Tamazian et al., 2009; Al-Mulali et al., 2015), while others claim that financial growth deteriorates environmental quality (See Javid and Sharif, 2016; Zang, 2011; Sadorsky, 2011). An economy's financial development can raise carbon dioxide emissions since it tends to attract FDI and trade to improve economic growth, which in turn increases carbon dioxide emissions (See, Frankel and Romer, 1999). Customers are also more likely to purchase cars and dwellings that release more carbon dioxide when they receive loans/credit (Sadorsky, 2010). However, our findings reveal that financial development (i.e., domestic credit to the private sector) reduces carbon dioxide emissions but not significantly. Financial development (i.e., credits) can contribute to environmental protection by lowering carbon dioxide emissions through the use of solar energy.

Lastly, a lot of studies are in line with our findings that economic growth, urban population, trade and industrialization affect environmental quality (i.e. carbon dioxide emissions). These studies are (Mahmood et al., 2020; Sarkodie and Strezov, 2019; Salahuddin et al., 2018; Akbostanci et al., 2011; Odugbesan and Rjoub, 2020; Wang et al., 2018; Bakirtas and Akpolat, 2018; Halicioglu, 2009).

\section{Conclusion}

Using time series data for Tanzania from 1990 to 2020, this study investigated the effects of economic growth, financial development (i.e. credit to the private sector), industrialization, trade, and urban population on environmental quality (i.e. carbon dioxide emissions). Our findings show that trade, industrialization, economic growth and urban population have positive and significant effects on environmental quality in the short run. However, the findings revealed that only economic growth leads to increases in carbon dioxide emissions in the long run. Also, economic growth is harmful to the environment above a threshold value of $6.23 \%$. In turn, the short and long run relationships between carbon dioxide emissions and financial development (i.e. credit) are negligible, but the negative coefficient indicates that it contributes to environmental protection by lowering carbon dioxide emissions through the use of solar energy. Our findings suggest that carbon dioxide emissions should be monitored and managed to protect the environmental quality through the use of given threshold value. Further, a strong focus should be placed on formulating environmental policies (i.e. carbon tax policy) as industrialization, urban population, economic growth and trade continue to grow in the future, restricting carbon dioxide emissions and safeguarding the environment. We recommend the government to promote renewable energy technologies and planning application of renewable energy projects in the country. This could be a major target of carbon dioxide reduction combined with a carbon tax policy.

\section{Declarations}

We declare no competing interest

\section{Acknowledgements}


I would like to thank the Institute of Rural Development Planning for providing an access online material through research for life program.

\section{Author's contributions}

Mwoya Byaro: Conceptualization, Methodology, Software, Writing- Reviewing and Editing,

Mwoya Byaro: Data curation, Writing- Original draft preparation.

Hozen Mayaya: Supervision, reviewing and editing

Gemma Mafwolo: Writing- Original draft preparation.

\section{Funding}

No source of funding for this research should be declared.

\section{Availability of data and materials}

The data was extracted from public available database (World Bank Development Indicators, 2020) Database.

\section{Ethics approval and consent to participate}

The manuscript does not involve human participants. Not applicable.

\section{Consent for publication}

The manuscript does not contain data from any individuals reported.

\section{References}

1. Ahad, M., \& Khan, W. (2016). Does globalization impede environmental quality in Bangladesh? The role of real economic activities and energy use.

2. Akbostancı, E., Tunç, G. İ., \& Türüt-Aşık, S. (2011). CO2 emissions of Turkish manufacturing industry: a decomposition analysis. Applied Energy, 88(6), 2273-2278.

3. Albiman, M. M., Suleiman, N. N., \& Baka, H. O. (2015). The relationship between energy consumption, CO2 emissions and economic growth in Tanzania. International Journal of Energy Sector Management.

4. Al-Mulali, U., Tang, C. F., \& Ozturk, I. (2015). Does financial development reduce environmental degradation? Evidence from a panel study of 129 countries. Environmental Science and Pollution Research, 22(19), 14891-14900.

5. Amran, A., Lee, S. P., \& Devi, S. S. (2014). The influence of governance structure and strategic corporate social responsibility toward sustainability reporting quality. Business Strategy and the 
environment, 23(4), 217-235.

6. Aslam, B., Hu, J., Shahab, S., Ahmad, A., Saleem, M., Shah, S. S. A., ... \& Hassan, M. (2021). The nexus of industrialization, GDP per capita and $\mathrm{CO} 2$ emission in China. Environmental Technology \& Innovation, 101674.

7. Asongu, S. A., \& Odhiambo, N. M. (2020a). Governance, CO2 emissions and inclusive human development in sub-Saharan Africa. Energy Exploration \& Exploitation, 38(1), 18-36.

8. Asongu, S. A., \& Odhiambo, N. M. (2020b). Economic development thresholds for a green economy in sub-Saharan Africa. Energy Exploration \& Exploitation, 38(1), 3-17.

9. Baalouch F., Ayadi S. D., HussaineyK. (2019)A study of the determinants of environmental disclosure quality: evidence from French listed companies, Journal of Management and Governance (2019) 23:939-971 https://doi.org/10.1007/s10997-019-09474-0.

10. Bakirtas, T., \& Akpolat, A. G. (2018). The relationship between energy consumption, urbanization, and economic growth in new emerging-market countries. Energy, 147, 110-121.

11. Behera, S. R., \& Dash, D. P. (2017). The effect of urbanization, energy consumption, and foreign direct investment on the carbon dioxide emission in the SSEA (South and Southeast Asian) region. Renewable and Sustainable Energy Reviews, 70, 96-106.

12. Boutabba, M. A. (2014). The impact of financial development, income, energy and trade on carbon emissions: evidence from the Indian economy. Economic Modelling, 40, 33-41.

13. Byaro, M. \& Lemnge, D. (2018). Does development assistant for health buy better results in maternal health in Tanzania? Evidence from autoregressive distributed lag model (ARDL). African Journal of Economic Review, 6(2), 61-73.

14. Byaro, M., \& Kinyondo, A. (2020). Institutional Quality Explains the Difference of Natural Gas Revenues to Contribute in the Economy: Empirical Evidence from Tanzania. African Journal of Economic Review, 8(3), 84-97.

15. Braam, G. J., de Weerd, L. U., Hauck, M., \& Huijbregts, M. A. (2016). Determinants of corporate environmental reporting: The importance of environmental performance and assurance. Journal of cleaner production, 129, 724-734.

16. Coan, T. G., \& Holman, M. R. (2008). Voting green. Social Science Quarterly, 89(5), 1121-1135.

17. Dong, H., Xue, M., Xiao, Y., \& Liu, Y. (2021). Do carbon emissions impact the health of residents? Considering China's industrialization and urbanization. Science of The Total Environment, 758, 143688.

18. Du, L., Wei, C., \& Cai, S. (2012). Economic development and carbon dioxide emissions in China: Provincial panel data analysis. China Economic Review, 23(2), 371-384.

19. Edmonds, H. K., Lovell, J. E., \& Lovell, C. A. K. (2020). A new composite climate change vulnerability index. Ecological Indicators, 117, 106529.

20. Efobi, U., Belmondo, T., Orkoh, E., Atata, S. N., Akinyemi, O., \& Beecroft, I. (2019). Environmental pollution policy of small businesses in Nigeria and Ghana: extent and impact. Environmental Science 
and Pollution Research, 26(3), 2882-2897.

21. Frankel, J. A., \& Romer, D. H. (1999). Does trade cause growth?. American economic review, 89(3), 379-399.

22. Frankel, J. A., \& Rose, A. K. (2005). Is trade good or bad for the environment? Sorting out the causality. Review of economics and statistics, 87(1), 85-91.

23. Grossman, G. M., \& Krueger, A. B. (1991). Environmental impacts of a North American free trade agreement.

24. Grossman, G. M., \& Krueger, A. B. (1995). Economic growth and the environment. The quarterly journal of economics, 110(2), 353-377.

25. Grossman, G. M., \& Krueger, A. B. (1996). The inverted-U: what does it mean?. Environment and Development Economics, 1(1), 119-122.

26. Guillaumont, P., \& Simonet, C. (2011). To what extent are African countries vulnerable to climate change? Lessons from a new Indicator of Physical Vulnerability to Climate Change. Development, 6 , 1-8.

27. Hakimi, A., \& Hamdi, H. (2016). Trade liberalization, FDI inflows, environmental quality and economic growth: a comparative analysis between Tunisia and Morocco. Renewable and Sustainable Energy Reviews, 58, 1445-1456.

28. Halicioglu, F. (2009). An econometric study of CO2 emissions, energy consumption, income and foreign trade in Turkey. Energy policy, 37(3), 1156-1164.

29. Heidari, H., Katircioğlu, S. T., \& Saeidpour, L. (2015). Economic growth, CO2 emissions, and energy consumption in the five ASEAN countries. International Journal of Electrical Power \& Energy Systems, 64, 785-791.

30. Ibrahim, M. H., \& Law, S. H. (2016). Institutional Quality and CO2 Emission-Trade Relations: Evidence from S ub-S aharan A frica. South African Journal of Economics, 84(2), 323-340.

31. Javid, M., \& Sharif, F. (2016). Environmental Kuznets curve and financial development in Pakistan. Renewable and Sustainable Energy Reviews, 54, 406-414.

32. Jedwab, R., \& Vollrath, D. (2015). Urbanization without growth in historical perspective. Explorations in Economic History, 58, 1-21.

33. Kahn, M. E. (2002). Demographic change and the demand for environmental regulation. Journal of Policy Analysis and Management: The Journal of the Association for Public Policy Analysis and Management, 21(1), 45-62.

34. Kolk, A., Levy, D., \& Pinkse, J. (2008). Corporate responses in an emerging climate regime: The institutionalization and commensuration of carbon disclosure. European accounting review, 17(4), 719-745.

35. Li, Z., Xu, N., \& Yuan, J. (2015). New evidence on trade-environment linkage via air visibility. Economics Letters, 128, 72-74. 
36. Li, G., \& Wei, W. (2021). Financial development, openness, innovation, carbon emissions, and economic growth in China. Energy Economics, 97, 105194.

37. Mahmood, H., Alkhateeb, T. T. Y., \& Furqan, M. (2020). Industrialization, urbanization and CO2 emissions in Saudi Arabia: Asymmetry analysis. Energy Reports, 6, 1553-1560.

38. Martínez-Zarzoso, I., \& Maruotti, A. (2011). The impact of urbanization on $\mathrm{CO} 2$ emissions: evidence from developing countries. Ecological Economics, 70(7), 1344-1353.

39. Muhammad, S., Long, X., Salman, M., \& Dauda, L. (2020). Effect of urbanization and international trade on $\mathrm{CO} 2$ emissions across 65 belt and road initiative countries. Energy, 196, 117102.

40. Murshed, M. (2021). Modeling primary energy and electricity demands in Bangladesh: An Autoregressive distributed lag approach. Sustainable Production and Consumption, 27, 698-712.

41. NBS.(2019).https://www.nbs.go.tz/index.php/en/census-surveys/environmental-statistics/593-thenational-climate-change-statistics-report-2019

42. Odugbesan, J. A., \& Rjoub, H. (2020). Relationship among economic growth, energy consumption, CO2 emission, and urbanization: evidence from MINT countries. Sage Open, 10(2), 2158244020914648.

43. Omri, A., Euchi, J., Hasaballah, A. H., \& Al-Tit, A. (2019). Determinants of environmental sustainability: evidence from Saudi Arabia. Science of The Total Environment, 657, 1592-1601.

44. Opoku, E. E. O., \& Aluko, O. A. (2021). Heterogeneous effects of industrialization on the environment: Evidence from panel quantile regression. Structural Change and Economic Dynamics, 59, 174-184.

45. Opoku, E. E. O., \& Boachie, M. K. (2020). The environmental impact of industrialization and foreign direct investment. Energy Policy, 137, 111178.

46. Pan American Health Organization (PAHO). Environmental Determinants of Health https://www.paho.org/en/topics/environmental-determinants-health Site visited on 21 Feb 2021 08:58

47. Pata, U. K. (2018). Renewable energy consumption, urbanization, financial development, income and $\mathrm{CO} 2$ emissions in Turkey: testing EKC hypothesis with structural breaks. Journal of Cleaner Production, 187, 770-779.

48. Pesaran, H.M. and Shin, Y. (1999). Autoregressive distributed lag modeling approach to cointegration analysis. Chapter 11, in storm, S., (Ed.) Econometrics and Economic Theory in the 20th. Century: The Ragnar Frisch Centennial Symposium. Cambridge: Cambridge University Press.

49. Pesaran, M.H., Shin, Y., \& Smith, R. J. (2001).Bounds Testing Approaches to the Analysis of Level Relationships. Journal of Applied Econometrics, 16, 289-326

50. Rehman, A., Ma, H., \& Ozturk, I. (2021). Do industrialization, energy importations, and economic progress influence carbon emission in Pakistan. Environmental Science and Pollution Research, 1-13

51. Ricci, F. (2007). Channels of transmission of environmental policy to economic growth: A survey of the theory. Ecological Economics, 60(4), 688-699. 
52. Sadorsky, P. (2010). The impact of financial development on energy consumption in emerging economies. Energy policy, 38(5), 2528-2535.

53. Sadorsky, P. (2011). Financial development and energy consumption in Central and Eastern European frontier economies. Energy policy, 39(2), 999-1006.

54. Salahuddin, M., Alam, K., Ozturk, I., \& Sohag, K. (2018). The effects of electricity consumption, economic growth, financial development and foreign direct investment on $\mathrm{CO} 2$ emissions in Kuwait. Renewable and Sustainable Energy Reviews, 81, 2002-2010.

55. Salari, M., Javid, R. J., \& Noghanibehambari, H. (2021). The nexus between $\mathrm{CO} 2$ emissions, energy consumption, and economic growth in the US. Economic Analysis and Policy, 69, 182-194.

56. Sarkodie, S. A., \& Ozturk, I. (2020). Investigating the environmental Kuznets curve hypothesis in Kenya: a multivariate analysis. Renewable and Sustainable Energy Reviews, 117, 109481.

57. Sarkodie, S. A., \& Strezov, V. (2019). Effect of foreign direct investments, economic development and energy consumption on greenhouse gas emissions in developing countries. Science of the Total Environment, 646, 862-871.

58. Shahbaz, M., Van Hoang, T. H., Mahalik, M. K., \& Roubaud, D. (2017). Energy consumption, financial development and economic growth in India: New evidence from a nonlinear and asymmetric analysis. Energy Economics, 63, 199-212.

59. Shaker, R. R. (2015). The spatial distribution of development in Europe and its underlying sustainability correlations. Applied Geography, 63, 304-314.

60. Statista(2021).https://www.statista.com/statistics/1228945/urban-population-intanzania/\#statisticContainer

61. Sun, H., Attuquaye Clottey, S., Geng, Y., Fang, K., \& Clifford Kofi Amissah, J. (2019). Trade openness and carbon emissions: Evidence from belt and road countries. Sustainability, 11(9), 2682.

62. Tamazian, A., Chousa, J. P., \& Vadlamannati, K. C. (2009). Does higher economic and financial development lead to environmental degradation: evidence from BRIC countries. Energy policy, 37(1), 246-253.

63. United Nations. (2015). The Millenium Development Goals, United Nations, New York.

64. Wang, S., Li, G., \& Fang, C. (2018). Urbanization, economic growth, energy consumption, and CO2 emissions: Empirical evidence from countries with different income levels. Renewable and Sustainable Energy Reviews, 81, 2144-2159.

65. WHO (2012) Social and environmental determinants of health and health inequalities in Europe: fact sheet: European Health for All databases [online database]. Copenhagen, WHO Regional Office for Europe, 2012 (http://data.euro.who.int/hfadb).

66. World Bank Development Indicators Database (2021). http://worldbank.

67. Xiangyang, D., \& Guiqiu, Y. (2011). China's Greenhouse Gas emissions' dynamic effects in the process of its urbanization: A perspective from shocks decomposition under long-term constraints. Energy Procedia, 5, 1660-1665. 
68. Xu, H., Zhao, G., Xie, R., \& Zhu, K. (2020). A trade-related CO2 emissions and its composition: Evidence from China. Journal of Environmental Management, 270, 110893.

69. Yameogo, C. E., Omojolaibi, J. A., \& Dauda, R. O. (2020). Economic Globalisation, Institutions and Environmental Quality in Sub-Saharan Africa. Research in Globalization, 100035.

70. Zafar, A., Ullah, S., Majeed, M. T., \& Yasmeen, R. (2020). Environmental pollution in Asian economies: Does the industrialisation matter?. OPEC Energy Review, 44(3), 227-248.

71. Zafar, M. W., Qin, Q., \& Zaidi, S. A. H. (2020). Foreign direct investment and education as determinants of environmental quality: The importance of post Paris Agreement (COP21). Journal of Environmental Management, 270, 110827.

72. Zhang, N., Yu, K., \& Chen, Z. (2017). How does urbanization affect carbon dioxide emissions? A cross-country panel data analysis. Energy Policy, 107, 678-687.

73. Zhang, T., Song, Y., \& Yang, J. (2021). Relationships between urbanization and CO2 emissions in China: An empirical analysis of population migration. PloS one, 16(8), e0256335.

74. Zhang, Y. J. (2011). The impact of financial development on carbon emissions: An empirical analysis in China. Energy policy, 39(4), 2197-2203.

75. Zhou, A., \& Li, J. (2020). The nonlinear impact of industrial restructuring on economic growth and carbon dioxide emissions: a panel threshold regression approach. Environmental Science and Pollution Research, 1-16.

76. Zhou, H., Cao, J., \& Sheng, J. (2013). The Effects of China-EU Trade on CO 2 Emissions. Low Carbon Economy, 4(04), 14.

\section{Figures}




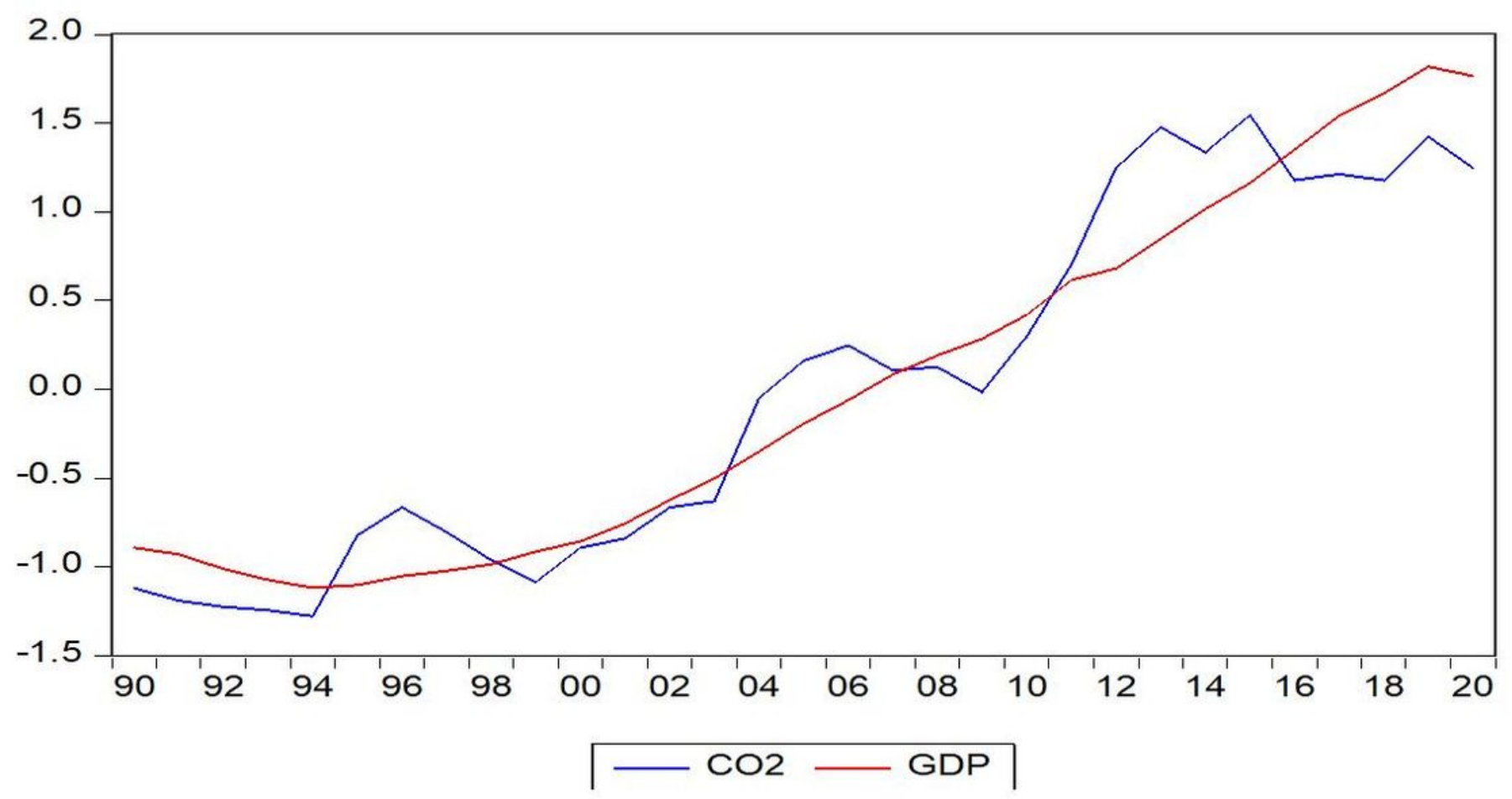

Figure 1

Normalized data showing the link between carbon dioxide emissions and GDP in Tanzania Akaike Information Criteria (top 20 models)

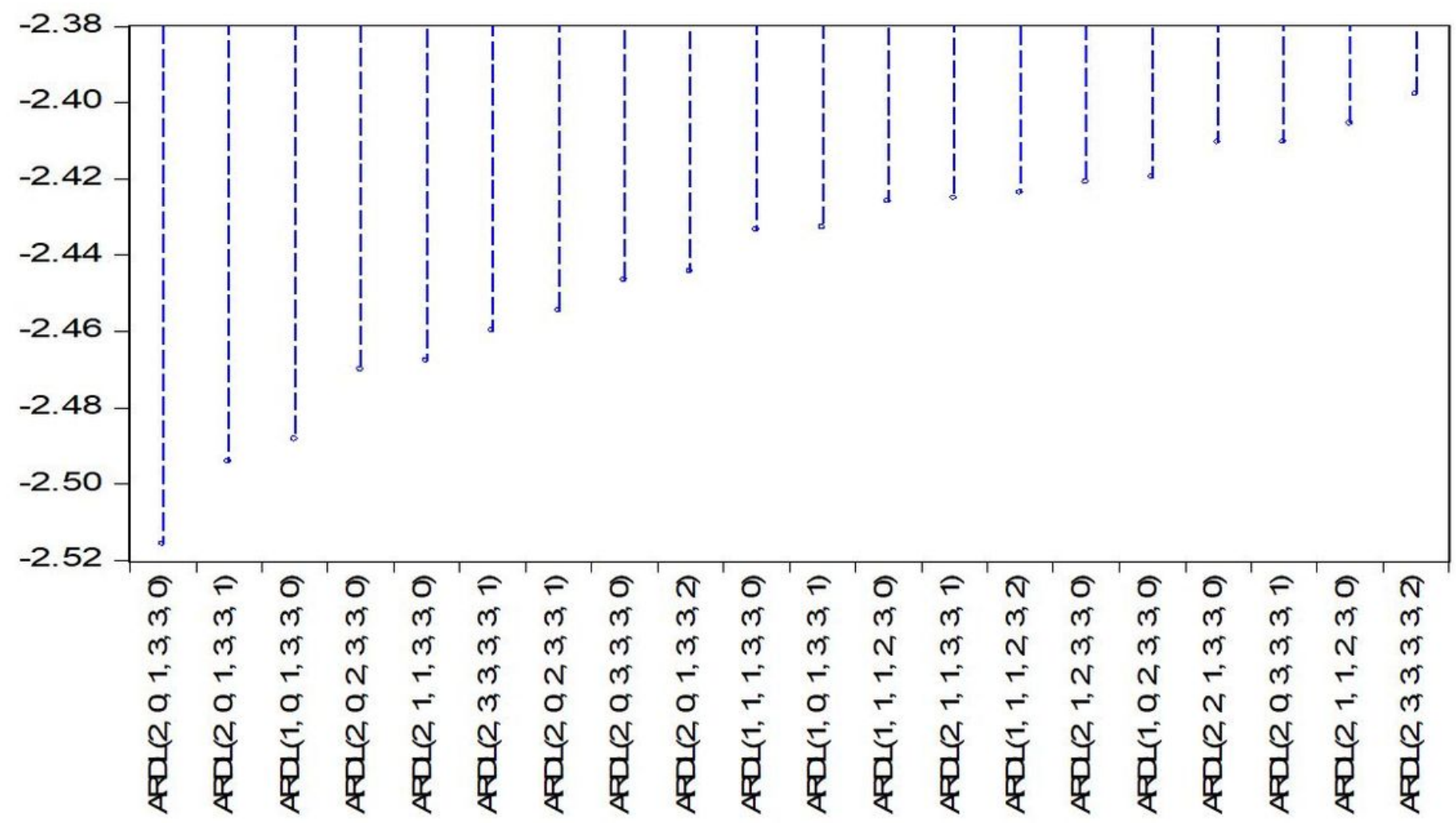

Figure 2 
AIC top 20 models criteria

Page 21/21 